\title{
Modelización y contraste experimental del comportamiento mecánico del vidrio laminado estructural
}

\section{Modelling and experimental contrast of the mechanical behaviour of structural laminated glass}

\author{
E. Sanz-Ablanedo ${ }^{(*)}$, M. J. Lamela(**), José. R. Rodríguez-Pérez(*), P. Arias(***)
}

\section{RESUMEN}

Este trabajo presenta la simulación numérica del comportamiento mecánico de placas de vidrio laminado (vidrio-PVB-vidrio) y su comprobación experimental. La caracterización viscoelástica de la lámina intermedia de PVB se ha realizado mediante ensayos de relajación de tensiones a diversas temperaturas. La consideración del PVB como material viscoelástico permite analizar la respuesta real del elemento estructural de vidrio laminado ante variaciones en el tiempo de la temperatura, de la velocidad de aplicación de las cargas, del estado tensional, etc. Los desplazamientos obtenidos numéricamente han sido contrastados experimentalmente en placas de vidrio laminado sometidas a carga lateral mediante fotogrametría de objeto cercano y relojes comparadores. Del análisis de los resultados se confirma el comportamiento variable en el tiempo del conjunto vidrio-PVB-vidrio y se deduce la validez de la modelización propuesta.

Palabras clave: vidrio laminado, PVB, viscoelasticidad, elemenentos finitos, fotogrametría.

\begin{abstract}
This paper presents a numerical simulation of the mechanical behaviour of laminated glass plates (glassPVB-glass) and its experimental verification. The viscoelastic characterization of the intermediate layer of PVB has been done by means of stress relaxation tests at various temperatures. The consideration of PVB as a viscoelastic material permits to analyze the real response of the structural element of laminated glass under time variations of temperature, of application of loading, of stress state, etc. Displacements obtained with the numerical analysis have been verified experimentally with laminated glass plates under lateral load using close range photogrammetry and dial gauges indicators. The analysis of results confirms the time dependent behaviour of the glass-PVB-glass laminate and suggests the validity of the proposed model.
\end{abstract}

Keywords: laminated glass, PVB, viscoelastícity, finite elements, photogrammetry.

(*) Universidad de León (Ponferrada, España).

(**) Universidad de Oviedo (Gijón, España).

$(* * *)$ Universidad de Vigo (Vigo, España). 


\section{INTRODUCCIÓN}

En las últimas décadas el uso del vidrio en la construcción ha experimentado un notable aumento, pasando de desempeñar una función secundaria como un mero componente en las ventanas, a una función estructural primaria en vigas, soportes y muy especialmente en fachadas de edificios altos y de otras construcciones singulares e industriales. Aunque con la incorporación del vidrio como material estructural se consiguen efectos arquitectónicos espectaculares, su comportamiento frágil y la posibilidad de una eventual rotura con resultados imprevisibles, exige aplicar metodologías de diseño rigurosas para alcanzar los niveles de seguridad exigidos en otros materiales, dado que la resistencia del vidrio depende de factores particulares tales como la presencia de defectos en su superficie, del tamaño del elemento estructural, la solicitación aplicada, etc.

Las metodologías de diseño para elementos de vidrio están cambiando en los últimos años pasando de ser metodologías basadas únicamente en datos experimentales a incluir procesos analíticos que permiten modelos más precisos, flexibles y generalizables.

El objetivo de esta comunicación es el de presentar una modelización numérica del comportamiento mecánico del vidrio laminado realizada con elementos finitos así como su comprobación experimental. Esta modelización tiene en cuenta la naturaleza viscoelástica del PVB en el cálculo del estado tensional, consiguiendo diseños en vidrio más precisos y seguros.

\section{DISEÑO DEL MODELO}

En la Figura 1 se muestra el mallado de elementos finitos utilizado para la modelización numérica en este trabajo y que es una modificación del propuesto en (1). Como se puede apreciar consiste en un cuarto de placa de dimensiones $L / 2 \times A / 2$ con 6 capas de elementos finitos por cada lámina de vidrio y 4 por la lámina de PVB teniendo cada capa un total de 400 elementos. Los elementos utilizados son elementos de 8 nodos con modos incompatibles y en el caso del PVB de formulación híbrida. La modelización ha sido resuelta usando el programa de elementos finitos ABAQUSTM (2).

El vidrio se modelizó como un sólido elástico (3) con las propiedades constitutivas mostradas en la Tabla 1 (4).

\section{INTRODUCTION}

In recent decades the use of glass in construction has increased dramatically, going to play a secondary role as a mere component in the windows, according to a primary structural beams, and especially in media facades of tall buildings and singular and industrial buildings. Although the incorporation of glass as a structural material achieves great architectural effects, their brittle behaviour and the possibility of an eventual break with unpredictable results, requires rigorous design methodologies to achieve the required safety levels in other materials, since the resistance glass depends on specific factors such as the presence of defects on the surface, the size of the structural element, the solicitation applied, etc.

Methodologies for design of glass elements are changing in recent years moving from methodologies based solely on experimental data to include analytical processes that allow more accurate models, flexible and generalizable.

The purpose of this communication is to present a numerical simulation of the mechanical behaviour of laminated glass made with finite element and its experimental verification. This analysis takes into account the viscoelastic nature of PVB in the calculation of stress state, obtaining more precise designs in glass and insurance.

\section{MODEL DESIGN}

Figure 1 shows the finite element mesh used for numerical modelling in this work and is a modification proposed in (1). As can be seen in one quarter of plate dimensions $L / 2 x A / 2$ with 6 layers of finite elements for each sheet of glass and 4 per sheet each PVB layer having a total of 400 elements. The elements used are 8 -node elements with incompatible modes and in the case PVB hybrid formulation. The model has been solved using the finite element ABAQUSTM (2).

The glass was modeled as an elastic solid (3) with the constitutive properties displayed in Table 1 (4).

Tabla 1 / Table 1

Propiedades constitutivas del vidrio. Constitutive properties of glass.

\begin{tabular}{|c|c|}
\hline Parámetro / Parameter & Valor / Value \\
\hline Densidad / Density & $2500 \mathrm{~kg} / \mathrm{m}^{3}$ \\
\hline Módulo de Young / Young's modulus & $70 \mathrm{Gpa}$ \\
\hline Módulo de Poisson / Poisson's modulus & 0.24 \\
\hline
\end{tabular}




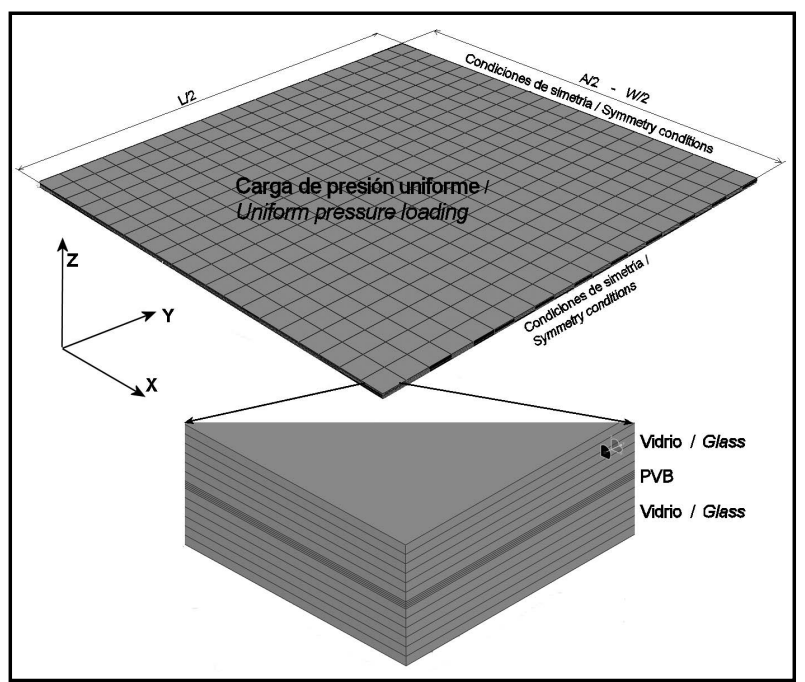

Figura 1. Mallado de elementos finitos para la geometría analizada. Figure 1. Finite element mesh for the geometry analyzed.

La lámina intermedia de PVB se modelizó como un material viscoelástico lineal (2), [1]:
The intermediate layer of PVB is modeled as a linear viscoelastic material (2), [1]:

$$
\begin{aligned}
& \sigma(t)=2 G_{O} e(t)+\int_{O}^{\tau} 2 \dot{G}\left(\tau^{\prime}\right) e\left(t-t^{\prime}\right) d \tau^{\prime}+I\left[K_{O} \phi(t)+\int_{0}^{\tau} \dot{K}\left(\tau^{\prime}\right) \phi\left(t-t^{\prime}\right) d \tau^{\prime}\right] \\
& \dot{G}\left(\tau^{\prime}\right)=d G\left(\tau^{\prime}\right) / d \tau^{\prime} \\
& \dot{K}\left(\tau^{\prime}\right)=d K\left(\tau^{\prime}\right) / d \tau^{\prime}
\end{aligned}
$$

donde $\sigma$ es la tensión en el instante $t$, $\tau$ es el tiempo reducido, $G_{O}$ y $K_{o}$ son los módulos iniciales de relajación a cortante y volumétrico, $G(t)$ y $K(t)$ son los módulos de relajación a cortante y volumétrico dependientes del tiempo. El tiempo reducido $\tau$ representa un desplazamiento en el tiempo con la temperatura y se relaciona con el tiempo actual a través de la ecuación diferencial [2]: where $\sigma$ is the tension at the moment $t, \tau$ is the reduced time, $G_{o}$ and $K_{o}$ are the instantaneous shear and bulk moduli, $G(t)$ y $K(t)$ are the shear and bulk moduli in small deformations and time-dependent. Reduced time $\tau$ is a shift in time with temperature and is related to the current time through the differential equation [2]:

$$
d \tau^{\prime}=\frac{d t^{\prime}}{A_{\theta}\left(\theta\left(t^{\prime}\right)\right)}
$$

donde $\theta$ es la temperatura y $A_{\theta}$ es la función de desplazamiento en el tiempo $t^{\prime}$. Frecuentemente esta función es aproximada por la ecuación Williams-Landel-Ferry (WLF) (5), [3]: where $\theta$ is the temperature and $A_{\theta}$ the role of displacement in time $t^{\prime}$. Often this equation is approximated by the Williams-Landel-Ferry (WLF) (5), [3]:

$$
\log (A)=-\frac{C_{1}\left(\theta-\theta_{0}\right)}{C_{2}+\left(\theta-\theta_{0}\right)}
$$

Donde $\theta_{o}$ es una temperatura de referencia y $C_{1}$ y $C_{2}$ son constantes características del material.

Para el PVB se adoptó el valor del módulo volumétrico, $K_{o}=2 \mathrm{GPa}$, independiente de la temperatura y del tiempo, por lo que según (1):
Where $\theta_{0}$ is an arbitrary reference temperature and $C_{1}$ and $C_{2}$ are two constants of the material.

For $P V B$, the value of $K_{o}=2 \mathrm{GPa}$ is taken independent of temperature and time, so that (1): 


$$
\dot{G}\left(\tau^{\prime}\right)=0
$$

Para la determinación de $G_{0}$ y $G(t)$ se realizaron ensayos de relajación de tensiones. Debido al pequeño espesor de las muestras de PVB no fue posible realizar ensayos a cortante, por lo que los ensayos de relajación de tensiones se realizaron a tracción, obteniéndose primeramente $E_{o}$ y $E(t)$ (Figura 2) para posteriormente convertirlos a $G_{o}$ y $G(t)$ a partir de la relación (6), [4]:

$$
G=\frac{3 E K}{9 K-E}
$$

De la misma forma, el módulo de Poisson se calculó a partir de datos experimentales [5]:

In the same way we calculated the Poisson modulus from the experimental data [5]:

$$
v=\frac{3 K-E}{6 K}=0,33
$$

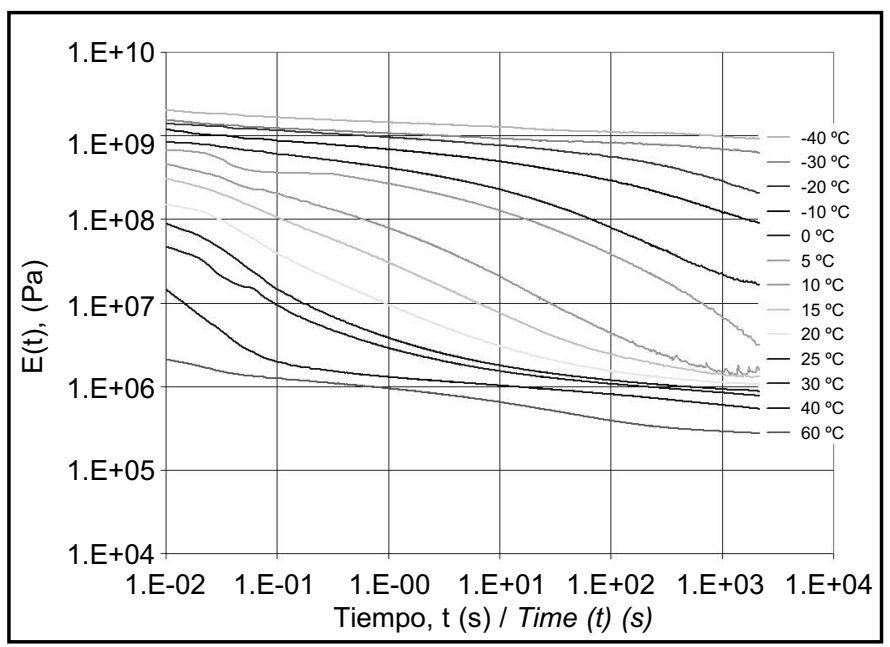

Figura 2. Módulos de relajación de tensiones $\mathrm{E}(\mathrm{t})$ obtenidos para ensayos a tracción a distintas temperaturas.

Figure 2. Moduli of relaxation $E(t)$ obtained for tension tests at different temperatures.

Mediante la aplicación del concepto de tiempo reducido $\tau$ a una temperatura de referencia $\theta_{O}=20^{\circ} \mathrm{C}$ y unas constantes $C_{1}=20,7$ y $C_{2}=91,1$, se obtuvo la curva maestra mostrada en la Figura 3, que representa el comportamiento a cortante del PVB para un amplio intervalo de tiempo.

Para posibilitar la implementación del módulo de relajación $\mathrm{G}(\mathrm{t})$ en el análisis de los elementos finitos, los datos experimentales se ajustaron a una curva a partir de una serie de Prony de $\mathrm{N}=12$ términos (Tabla 2) (7), [6]:
By applying the concept of reduced time $\tau$, a reference temperature $\theta_{O}=20^{\circ} \mathrm{C}$ and constants $C_{1}=20.7$ and $C_{2}=91.1$, the master curve obtained is shown in Figure 3, representing the shear behaviour of PVB for a wide range of time.

To enable the implementation of the relaxation modulus $G(t)$ within the finite element computations experimental data were adjusted to a series of Prony of $N=12$ terms (Table 2) (7), [6]:

$$
\begin{aligned}
& g_{R}(t)=1-\sum_{i=1}^{N} \bar{g}_{i}^{p}\left(1-e^{-t / \tau_{i}^{G}}\right) \\
& \bar{g}_{i}^{p} \text { y } \tau_{i}^{G} \text { para } i=1,2, \ldots, N=\text { Ctes. del material }
\end{aligned}
$$


Para el PVB ensayado los valores de estas constantes se muestran en la Tabla 2.

En el modelo numérico, a los bordes exteriores del $1 / 4$ de placa se les impuso la restricción de simplemente apoyados, mientras que a los correspondientes a los ejes de la placa se les impuso condiciones de simetría. Las cargas, velocidades de aplicación de carga y duración de las mismas se definieron de acuerdo a cada uno de los ensayos del programa experimental.
These constants for the PVB under study are shown in Table 2.

The outer edges of the $1 / 4$ plate is of the restriction imposed on them simply supported while the corresponding to the axes of the plate were imposed symmetry conditions. Loads, implementing velocities loading and duration of these were defined according to each test of the test program.

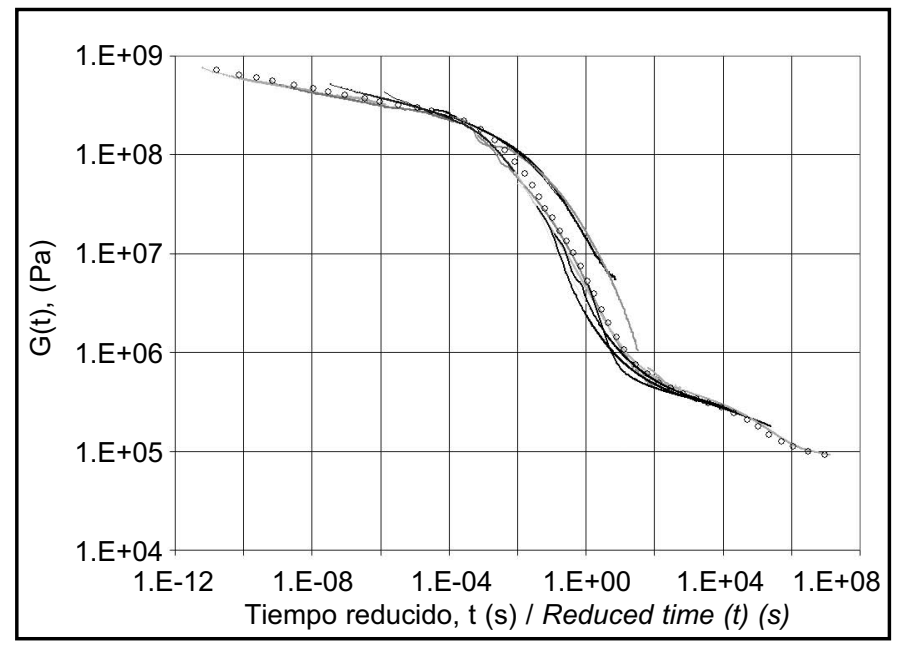

Figura 3. Comportamiento viscoelástico del PVB (módulo de relajación a cortante $\mathrm{G}(\mathrm{t})$ ), utilizando una temperatura de referencia $\theta_{0}=20^{\circ} \mathrm{C}$ y el concepto de tiempo reducido.

Figure 3. Viscoelastic behaviour of PVB (shear relaxation modulus $G(t)$ ), using a reference temperature $\theta_{0}=20^{\circ} \mathrm{C}$ and the concept of reduced time.

Tabla 2 / Table 2

Coeficientes de la serie de Prony. $t_{i}$ es el tiempo reducido y $g_{i}$ son los coeficientes de Prony

Coefficients of the Prony series. $t_{i}$ is the reduced time and $g_{i}$ are the Prony's coefficients.

\begin{tabular}{|c|c|c|}
\hline $\mathbf{N}$ & $t_{i}$ & $g_{i}$ \\
\hline $\mathbf{1}$ & $4.15319 \mathrm{E}-07$ & 0.00810847 \\
\hline $\mathbf{2}$ & $6.37616 \mathrm{E}-06$ & 0.247609 \\
\hline $\mathbf{3}$ & $9.78897 \mathrm{E}-05$ & 0.2948 \\
\hline $\mathbf{4}$ & 0.00150285 & 0.251571 \\
\hline $\mathbf{5}$ & 0.0230724 & 0.154831 \\
\hline $\mathbf{7}$ & 0.354217 & 0.0360304 \\
\hline $\mathbf{8}$ & 5.4381 & 0.00487183 \\
\hline $\mathbf{9}$ & 83.4882 & 0.000882527 \\
\hline $\mathbf{1 0}$ & 1281.75 & 0.000293609 \\
\hline $\mathbf{1 2}$ & 19678 & 0.000286321 \\
\hline
\end{tabular}

\section{DISEÑO DEL PROGRAMA EXPERIMENTAL}

Para la comprobación experimental de los resultados arrojados por el análisis numérico con elementos finitos se han utilizado 3 placas de vidrios suministrados por la empresa Vitro Cristal Glass y fabricados por Cristalería Española. Las dimensiones principales de las placas fueron

\section{PROGRAM EXPERIMENTAL DESIGN}

For the experimental verification of the results obtained by numerical analysis with finite elements have been used 3 plates of laminated glass supplied by the company Vitro Cristal Glass and manufactured by Cristalería Española. The principal dimensions of the 
$1404 \times 1404 \mathrm{~mm}$. El grosor de las placas P1 y P2 fue de 3 $\mathrm{mm}+0,38 \mathrm{~mm}+3 \mathrm{~mm}$ mientras que para la placa $\mathrm{P} 3$ el grosor fue de $4 \mathrm{~mm}+0,38 \mathrm{~mm}+4 \mathrm{~mm}$.

Las placas de vidrio laminado se instalaron verticalmente en una bancada diseñada siguiendo criterios de máxima igualdad a la situación real de servicio. Las placas se instrumentaron con dianas codificadas en los puntos de medición. La presión y el caudal de aire se regularon con un regulador de precisión y un caudalímetro.

Se realizaron dos ensayos cuyo objetivo era comprobar si las flechas predichas en el análisis numérico se correspondían con las medidas experimentales. Adicionalmente se realizó un tercer ensayo de contraste donde se verificó la exactitud de la metodología contrastando las mediciones fotogramétricas con las de un reloj comparador.

En el primer ensayo se sometió el banco de ensayos a 3 velocidades distintas de incrementos de presión: $6 \mathrm{~Pa} / \mathrm{s}$, $10 \mathrm{~Pa} / \mathrm{s}$ y $20 \mathrm{~Pa} / \mathrm{s}$, desde el reposo hasta los $2.000 \mathrm{~Pa}$. La toma de datos se realizó a intervalos regulares: $0 \mathrm{~Pa}$, $250 \mathrm{~Pa}, 500 \mathrm{~Pa}, 750 \mathrm{~Pa}, 1.000 \mathrm{~Pa}, 1.250 \mathrm{~Pa}, 1.500 \mathrm{~Pa}$, $1.750 \mathrm{~Pa}$ y $2.000 \mathrm{~Pa}$. El ensayo se repitió, para cada velocidad, un número mínimo de 3 veces para conseguir valores medios más fiables. En el segundo ensayo, se procedió a la puesta en carga de las 3 placas consideradas desde los $0 \mathrm{~Pa}$ hasta los $2.000 \mathrm{~Pa}$ en un tiempo de $120 \mathrm{~s}$ manteniendo posteriormente constante la presión durante 11,5 minutos. Durante este tiempo se realizaron medidas experimentales mediante levantamientos fotogramétricos a intervalos regulares de tiempo (30 s).

La mayor dificultad encontrada en la ejecución del ensayo estuvo relacionada con el mantenimiento de la presión dentro del banco de ensayos debido a la propia deformación de la placa, el cambio de temperatura del aire y las inevitables fugas. Debido a la dificultad experimental que supuso la toma de datos cada ensayo se repitió un número mínimo de 5 veces para conseguir valores medios más fiables. Las medidas se realizaron mediante fotogrametría de objeto cercano (8). Para ello plates were $1404 \times 1404 \mathrm{~mm}$. The thickness of the plates $P 1$ and $P 2$ was $3 \mathrm{~mm}+0.38 \mathrm{~mm}+3 \mathrm{~mm}$ while for $P 3$ plate thickness was $4 \mathrm{~mm}+0.38 \mathrm{~mm}+4 \mathrm{~mm}$.

The laminated glass plates were installed vertically in a frame designed according to criteria of maximum equal to the actual service. The plates were implemented with coded targets in the measurement points. Pressure and air flow is regulated with a precision regulator and a flowmeter.

Two tests were conducted whose objectives was to verify whether the predicted deflections in the numerical analysis correspond to the experimental measurements. Additionally we conducted a third test contrast veryfing the accuracy of the photogrammetric measurement with a dial gauge indicator.

In the first test the bench was put under test at 3 different speeds increases pressure: $6 \mathrm{~Pa} / \mathrm{s}, 10 \mathrm{~Pa} / \mathrm{s}$ and $20 \mathrm{~Pa} / \mathrm{s}$ from rest to $2000 \mathrm{~Pa}$. Data capture was performed at regular intervals: $0 \mathrm{~Pa}, 250 \mathrm{~Pa}, 500 \mathrm{~Pa}, 750$ $\mathrm{Pa}, 1000 \mathrm{~Pa}, 1250 \mathrm{~Pa}, 1500 \mathrm{~Pa}, 1750 \mathrm{~Pa}$ and $2000 \mathrm{~Pa}$. The test was repeated for each speed, a minimum of 3 times to obtain more reliable values. In the second test, proceeded to load up the 3 plates from $0 \mathrm{~Pa}$ to $2000 \mathrm{~Pa}$ in a time of $120 \mathrm{~s}$ then maintaining constant pressure during 11.5 minutes. During this time, experimental measurements were carried out by photogrammetric surveys at regular intervals of time (30 s).

The greatest difficulty encountered in the test was related to the sustain of the necessary pressure inside the test because of the deformation of the plate, the change of air temperature and the inevitable leaks. Because of the experimental difficulty each test is repeated a minimum of 5 times to obtain more reliable values. The measures were performed using close range photogrammetry (8). This will take high-resolution images (12 Mpixel) with 4 synchronized cameras Pentax

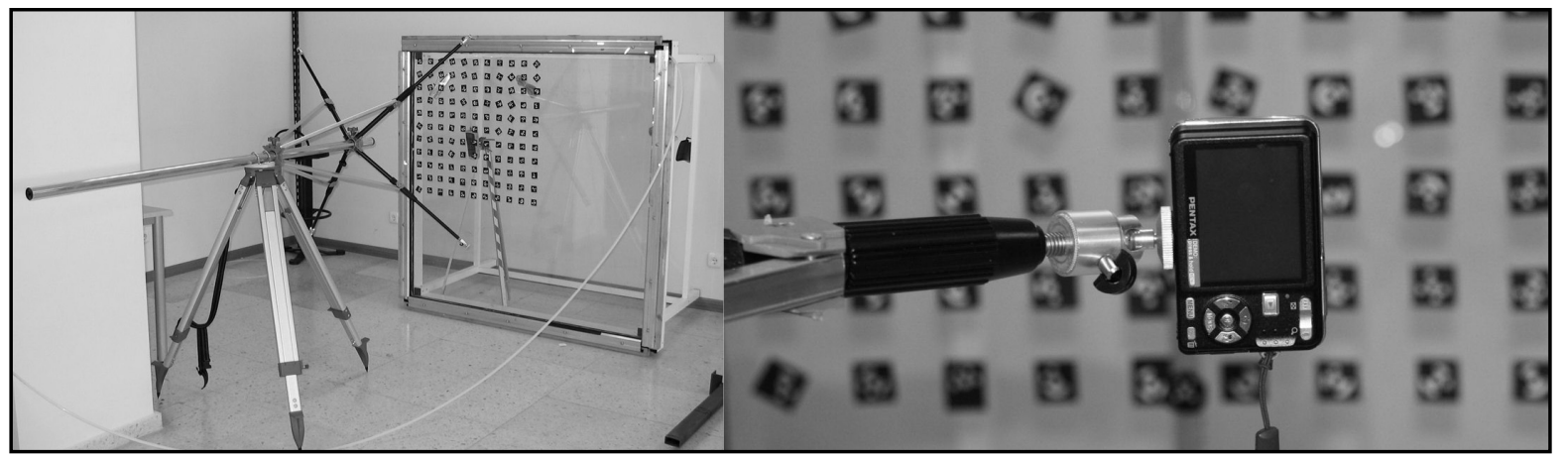

Figura 4. (Izquierda) Vista general del banco de ensayos y equipo de medición. (Derecha) Detalle de una de las cámaras utilizadas. Figure 4. (Left) Overview of test bench and measurement equipment. (Right) Detail of one of the cameras used. 
se tomaron imágenes de alta resolución (12 Mpixel) con 4 cámaras sincronizadas Pentax Optio A40 y dispuestas según una red especialmente diseñada (Figura 4).

\section{RESULTADOS Y ANÁLISIS}

En la Figura 5 y en la Figura 8 se muestran las flechas predichas por el análisis numérico para placas de 6,38 $\mathrm{mm}$ y de $8,38 \mathrm{~mm}$ cuando se les somete a presión creciente a 3 velocidades distintas: $6 \mathrm{~Pa} / \mathrm{s}, 12 \mathrm{~Pa} / \mathrm{s}$ y 20 $\mathrm{Pa} / \mathrm{s}$. En la Figura 6 y Figura 7 se muestran los respectivos resultados experimentales obtenidos por las placas P1 y P2 (6,38 mm). En la Figura 9 se muestran los resultados de la placa P3 $(8,38 \mathrm{~mm})$. A la derecha se ha representado un detalle de las flechas del último tramo entre $1.750 \mathrm{~Pa}$ y $2.000 \mathrm{~Pa}$.

Para poder comparar los resultados a distintas velocidades se han utilizado tanto en la predicción como en los resultados experimentales las diferencias entre las flechas obtenidas tomando como base las flechas obtenidas a $20 \mathrm{~Pa} / \mathrm{s}$. En la Tabla 3 se muestran los valores numéricos obtenidos.
Optio A40 and arranged according to a specially designed network (Figure 4).

\section{RESULTS AND ANALYSIS}

Figure 5 and Figure 8 show the predicted deflection by numerical analysis for plates of $6.38 \mathrm{~mm}$ and $8.38 \mathrm{~mm}$ when they are subjected to increasing pressure at 3 different speeds: $6 \mathrm{~Pa} / \mathrm{s}, 12 \mathrm{~Pa} / \mathrm{s}$ and $20 \mathrm{~Pa} / \mathrm{s}$. Figure 6 and Figure 7 show the respective experimental results obtained by the plates $P 1$ and $P 2(6.38 \mathrm{~mm})$. Figure 9 shows the results of the plate $P 3(8.38 \mathrm{~mm})$. To the right is represented a detail of the deflection on the last step between $1750 \mathrm{~Pa}$ and $2000 \mathrm{~Pa}$.

To compare results at different speeds have been used in the prediction and the experimental differences between the deflection obtained based on the deflections obtained at $20 \mathrm{~Pa} / \mathrm{s}$. Table 3 shows the numerical values obtained.

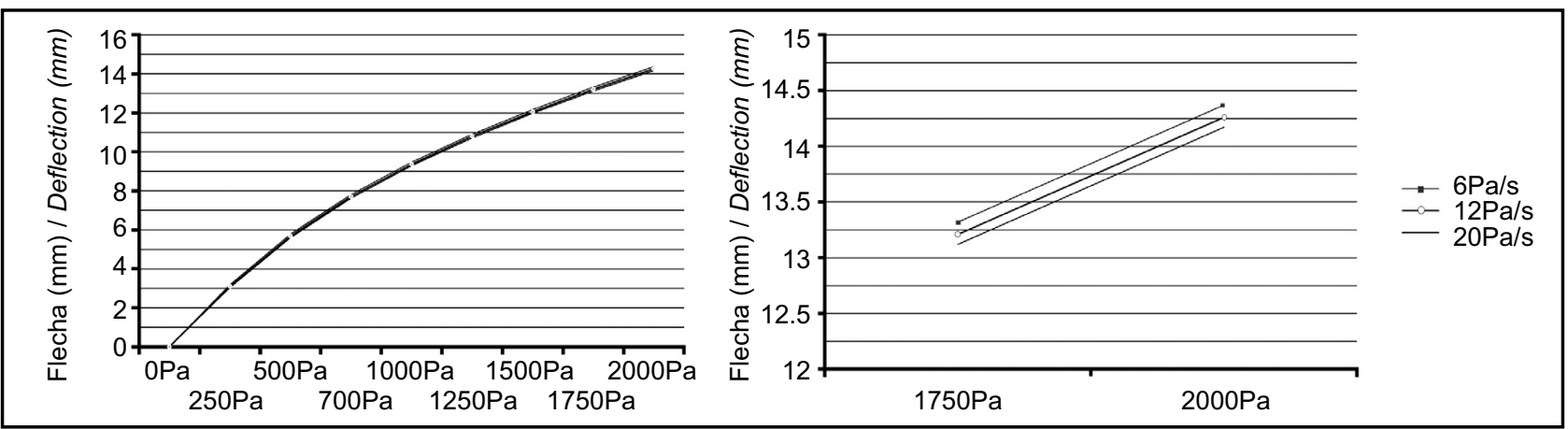

Figura 5. Flecha predicha mediante análisis numérico para una placa de vidrio laminado de $3+0,38+3 \mathrm{~mm}$. A la derecha, detalle entre 1.750 y $2.000 \mathrm{~Pa}$.

Figure 5. Predicted deflection by numerical simulation for a laminated glass plate of $3+0.38+3 \mathrm{~mm}$. On the right detail between 1750 and $2000 \mathrm{~Pa}$.
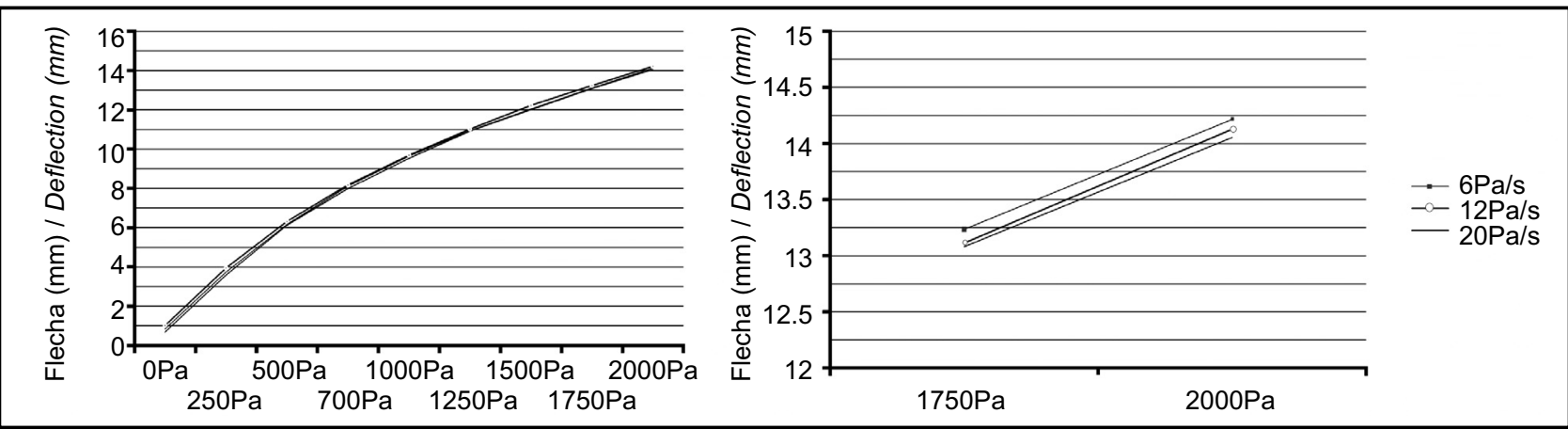

Figura 6. Flecha medida experimentalmente en el centro de la placa en la placa P1. A la derecha, detalle entre 1.750 y 2.000 Pa. Figure 6. Deflection experimentally measured in the center of the plate on the plate P1. On the right detail between 1750 and $2000 \mathrm{~Pa}$. 

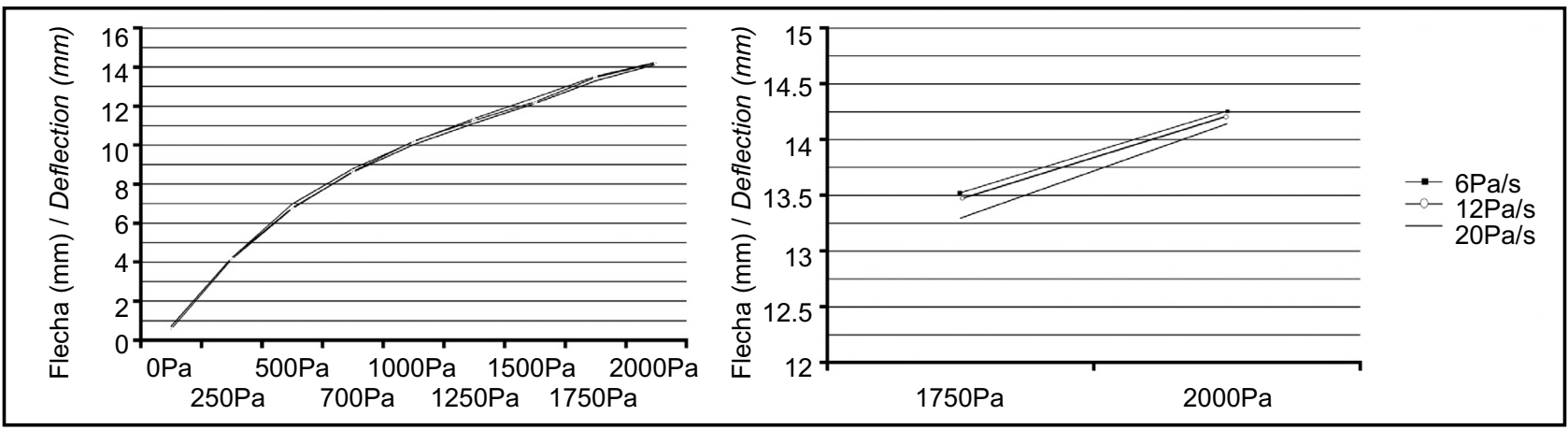

Figura 7. Flecha medida experimentalmente en el centro de la placa P2. A la derecha, detalle del último tramo entre 1.750 y 2.000 Pa. Figure 7. Deflection experimentally measured at the center of the plate P2. On the right detail between 1750 and 2000 Pa.
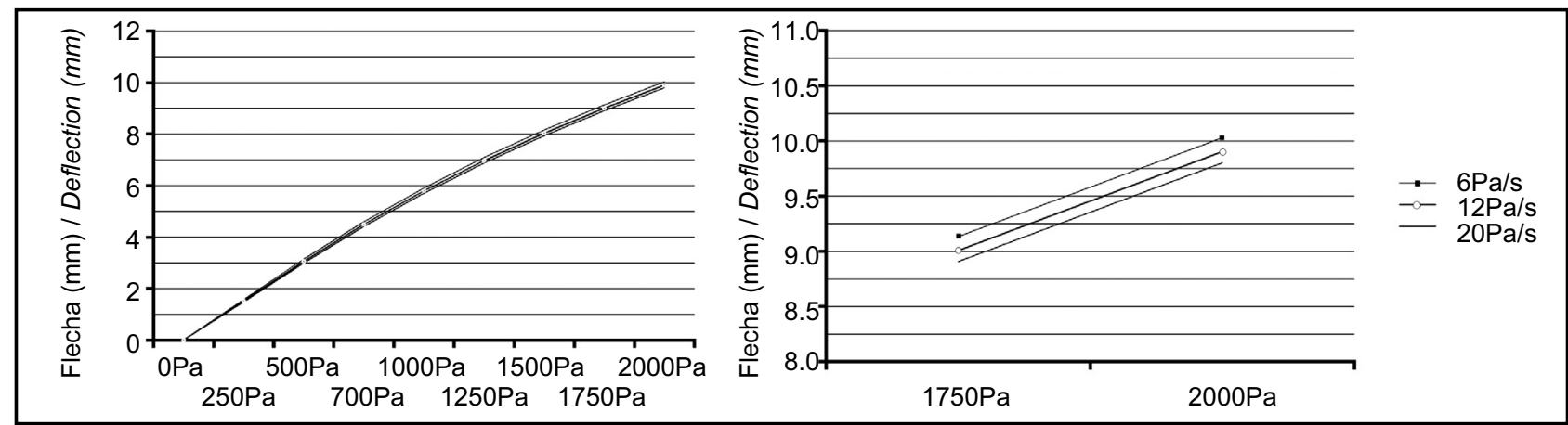

Figura 8. Flecha predicha mediante análisis numérico para una placa de vidrio laminado de $4+0,38+4 \mathrm{~mm}$. A la derecha, detalle entre 1.750 y $2.000 \mathrm{~Pa}$.

Figure 8. Predicted deflection by numerical simulation of a laminated glass plate of $4+0.38+4 \mathrm{~mm}$. On the right detail between 1750 and $2000 \mathrm{~Pa}$.
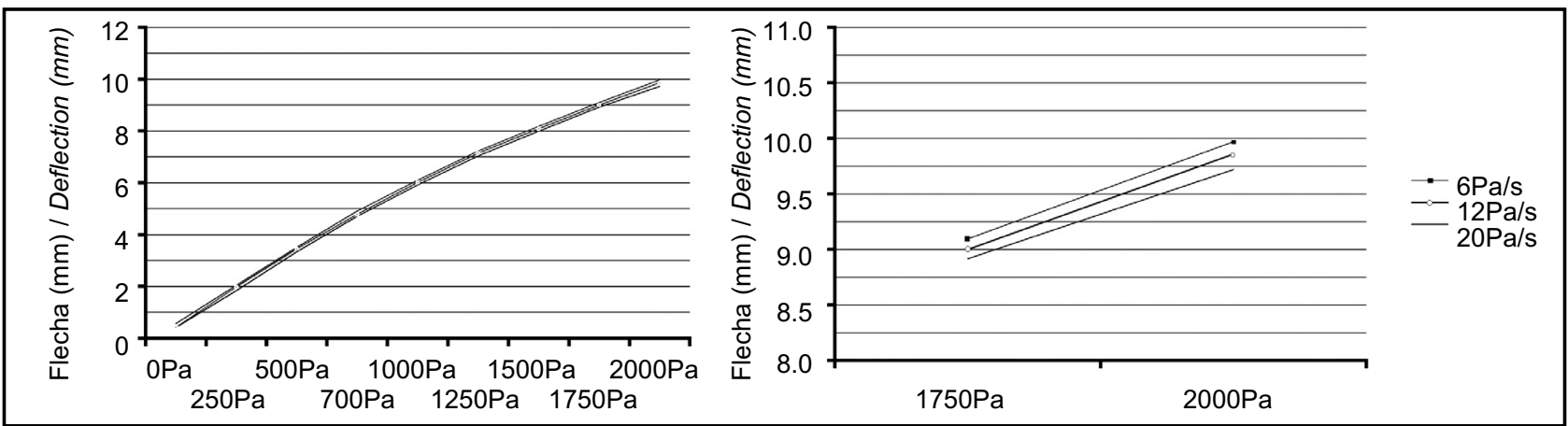

Figura 9. Flecha medida experimentalmente en el centro de la placa P3. A la derecha, detalle entre 1.750 y $2.000 \mathrm{~Pa}$. Figure 9. Deflection experimentally measured at the center of the plate P3. On the right detail between 1750 and $2000 \mathrm{~Pa}$.

Primeramente se observa que a $0 \mathrm{~Pa}$ las diferencias experimentales no son nulas como lógicamente sucede en la simulación. La razón es que en la simulación numérica se parte de una placa perfecta en dimensiones y en relajación total mientras que en los ensayos, dada la naturaleza viscoelástica del PVB, la placa inicialmente nunca está en reposo y siempre hay una deformación residual procedente no sólo del anterior ensayo sino también de toda la historia deformacional de la placa desde el mismo momento de su fabricación. Además de
First it is noted that a 0 Pa differences are not zero as in the numeric simulation. The reason is that the numerical simulation of a plate is perfect in size and total relaxation while in the tests, due to the viscoelastic nature of PVB, the plate is never at rest initially and there is always a residual strain derived not only from previous tests but also throughout the deformational history of the plate from the time of manufacture. In addition to the viscoelastic nature of PVB other technical difficulties associated with such precise control of pressure or the 
Tabla 3 / Table 3

Diferencias de flecha entre las distintas velocidades de deformación tomando como base las obtenidas a $20 \mathrm{~Pa} / \mathrm{s}$. Deflection differences between different speeds of deformation based on those obtained at $20 \mathrm{~Pa} / \mathrm{s}$.

\begin{tabular}{|c|c|c|c|c|c|c|c|c|c|c|}
\hline \multirow{4}{*}{$\begin{array}{c}\text { Presión I } \\
\text { Pressure } \\
\quad \text { (Pa) }\end{array}$} & \multicolumn{6}{|c|}{$3+0.38+3 \mathrm{~mm}$} & \multicolumn{4}{|c|}{$4+0.38+4 \mathrm{~mm}$} \\
\hline & \multirow{2}{*}{\multicolumn{2}{|c|}{$\begin{array}{l}\text { Calculadas por E.F. I } \\
\text { Calculated by F.E. }\end{array}$}} & \multicolumn{4}{|c|}{ Experimental / Experimental } & \multirow{2}{*}{\multicolumn{2}{|c|}{$\begin{array}{l}\text { Calculadas por E.F.I } \\
\text { Calculated by F.E. }\end{array}$}} & \multirow{2}{*}{\multicolumn{2}{|c|}{$\begin{array}{c}\begin{array}{c}\text { Experimental I } \\
\text { Experimental }\end{array} \\
\text { P3 }\end{array}$}} \\
\hline & & & \multicolumn{2}{|c|}{ P1 } & \multicolumn{2}{|c|}{ P2 } & & & & \\
\hline & $12 \mathrm{~Pa} / \mathrm{s}$ & $6 \mathrm{~Pa} / \mathrm{s}$ & $12 \mathrm{~Pa} / \mathrm{s}$ & $6 \mathrm{~Pa} / \mathrm{s}$ & $12 \mathrm{~Pa} / \mathrm{s}$ & $6 \mathrm{~Pa} / \mathrm{s}$ & $12 \mathrm{~Pa} / \mathrm{s}$ & $6 \mathrm{~Pa} / \mathrm{s}$ & $12 \mathrm{~Pa} / \mathrm{s}$ & $6 \mathrm{~Pa} / \mathrm{s}$ \\
\hline 0 & 0.000 & 0.000 & 0.154 & 0.333 & -0.149 & -0.016 & 0.000 & 0.000 & 0.005 & 0.144 \\
\hline 250 & 0.070 & 0.148 & 0.156 & 0.358 & -0.081 & -0.009 & 0.044 & 0.094 & 0.144 & 0.207 \\
\hline 500 & 0.084 & 0.178 & 0.039 & 0.200 & -0.040 & 0.199 & 0.071 & 0.153 & 0.113 & 0.169 \\
\hline 750 & 0.081 & 0.179 & 0.122 & 0.190 & 0.031 & 0.177 & 0.084 & 0.186 & 0.077 & 0.202 \\
\hline 1000 & 0.079 & 0.181 & 0.109 & 0.158 & 0.178 & 0.157 & 0.090 & 0.204 & 0.095 & 0.182 \\
\hline 1250 & 0.081 & 0.186 & 0.029 & 0.104 & 0.142 & 0.242 & 0.094 & 0.216 & 0.104 & 0.187 \\
\hline 1500 & 0.083 & 0.192 & 0.039 & 0.232 & 0.078 & 0.292 & 0.096 & 0.222 & 0.098 & 0.189 \\
\hline 1750 & 0.087 & 0.198 & 0.032 & 0.154 & 0.171 & 0.227 & 0.099 & 0.226 & 0.083 & 0.179 \\
\hline 2000 & 0.090 & 0.203 & 0.073 & 0.161 & 0.068 & 0.114 & 0.101 & 0.227 & 0.139 & 0.251 \\
\hline
\end{tabular}

la naturaleza viscoelástica del PVB otras dificultades técnicas relacionadas por ejemplo con el control preciso de la presión o la naturaleza dinámica del ensayo influyen en la dispersión de los datos. Por estas razones, los datos mostrados en la Tabla 3 son valores medios de varios ensayos.

A pesar de la dispersión de los datos, las tendencias en los datos experimentales verifican las predicciones de la simulación numérica. En primer lugar, las diferencias de flechas crecen con el nivel de presión, tanto a la velocidad de $12 \mathrm{~Pa} / \mathrm{s}$ como a la de $6 \mathrm{~Pa}$ /s. En segundo lugar, a menor velocidad de incremento de presión la flecha también es mayor. Esto significa que la mayor relajación de tensiones a cortante que tiene lugar como consecuencia del mayor tiempo disponible se traduce en un deslizamiento relativo entre placas y en última instancia en una mayor flecha. En tercer lugar, las diferencias de flecha obtenidas entre la mayor y la menor velocidad de incremento de presión coinciden. Esta diferencia puede establecerse en torno a 0,2 $\mathrm{mm}$ en los valores altos de presión.

Finalmente y según se observa en la Figura 6 y la Figura 7 el valor absoluto de las flechas medidas en las placas $\mathrm{P} 1$ y $\mathrm{P} 2$ difiere del valor predicho en el análisis numérico en tan sólo 0,2 mm. Lo mismo se comprueba para la placa P3 (Figura 9) donde la diferencia está en torno a $0,25 \mathrm{~mm}$. Por todo ello la verificación de la simulación es positiva en este ensayo.

Los resultados obtenidos en el segundo ensayo se han representado en la Figura 10 para las placas $\mathrm{P} 1$ y $\mathrm{P} 2$ y en la Figura 11 para la placa P3. En estas mismas figuras se han incluido los valores predichos a partir de la simulación numérica. nature of the test dynamics influencing the dispersion of data. For these reasons the data shown in Table 3 are averages of several tests.

Despite the dispersion of the data, experimental trends are consistent with predictions of numerical simulation. First, the differences in deflections grow with pressure level, both at the speed of $12 \mathrm{~Pa} / \mathrm{s}$ as that of $6 \mathrm{~Pa} / \mathrm{s}$. Second to lowest rate of pressure increase is also greater the deflection. This means that the further relaxation of shear stress that occurs as a result of the increased time available will result in a relative sliding between plates and ultimately greater deflection. Third, differences between deflection at highest and lowest rate of increase in pressure line are coincident. This difference may be about $0.2 \mathrm{~mm}$ in the high pressure.

Finally, as noted in the Figure 6 and Figure 7, the absolute value measures the deflection on the plates $P 1$ and $P 2$ differs from the value predicted in the numerical simulation in just $0.2 \mathrm{~mm}$. The same is true for the plate P3 (Figure 9) where the difference is around $0.25 \mathrm{~mm}$. Therefore the verification of the simulation in this test is positive.

The results obtained in the second test are shown in Figure 10 for the plates $P 1$ and $P 2$ and in Figure 11 for the plate P3. In these figures have been included the predicted values from the numerical simulation. 


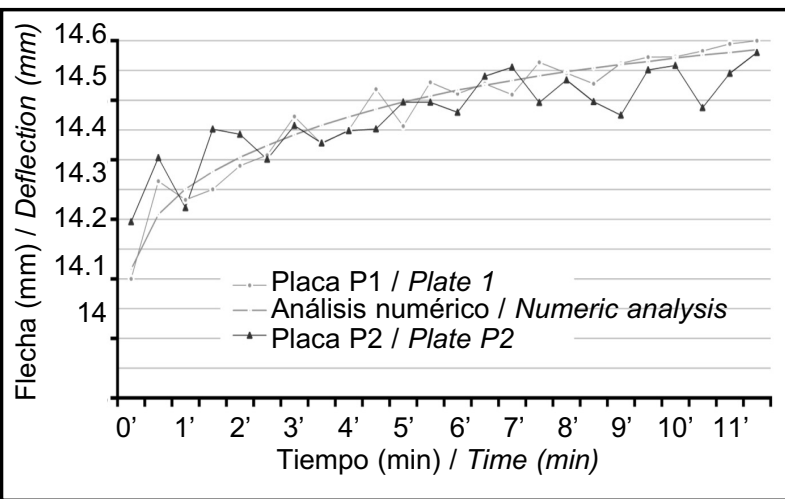

Figura 10. Flechas en el centro de la placa obtenidas experimentalmente en las placas P1 y P2, de $6,38 \mathrm{~mm}$ de espesor nominal, y flechas predichas por el análisis numérico de elementos finitos para una placa del mismo espesor. Figure 10. Deflection at the center of the plate obtained experimentally on the plates $P 1$ and $P 2$, of nominal thickness of $6.38 \mathrm{~mm}$ and deflection predicted by numerical analysis of finite elements for a plate thickness.

En estos resultados nuevamente se confirma la validez de la simulación numérica. Tal y como se puede apreciar en la Figura 10 y en la Figura 11 el mantenimiento en el tiempo de una presión constante provoca en el vidrio laminado un aumento de la flecha no despreciable. Así pues en las placas ensayadas puestas a 2.000 Pa de presión en un tiempo inicial de $120 \mathrm{~s}$ pasan a tener al cabo de 11,5 min una flecha un 2,5\% mayor tanto en el caso de la placa de $6,38 \mathrm{~mm}$ como en el de $8,38 \mathrm{~mm}$.

\section{CONCLUSIONES}

De la discusión de los resultados de este trabajo puede concluirse que las predicciones de la modelización numérica aquí presentada se corresponden en buena medida con lo observado experimentalmente. Los ensayos realizados no se han limitado a la medición de una flecha final una vez aplicada una carga sino que se ha tenido en cuenta la naturaleza viscoelástica de la lámina polimérica de PVB que se encuentra en los vidrios laminados realizándose ensayos a diferentes velocidades de aplicación de cargas y mantenimiento de las mismas a lo largo del tiempo. De los ensayos realizados se ha comprobado de una forma efectiva la influencia mecánica que ejerce la lámina polimérica sobre el conjunto del vidrio laminado lo que en último término implica la variación tensional de los elementos de vidrio. Así, al incrementarse la velocidad de carga la flecha obtenida es menor para un instante dado debido a que hay menos tiempo para la fluencia del material viscoelástico. Por otro lado se ha comprobado que con el transcurrir del tiempo el desplazamiento relativo entre las láminas de vidrio a favor de la lámina viscoelástica

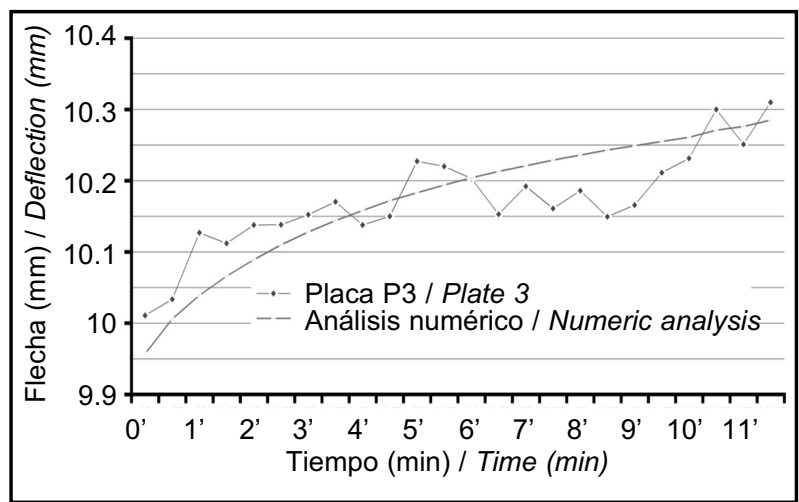

Figura 11. Flechas en el centro de la placa obtenidas experimentalmente en la placa P3 de 8,38 mm de espesor nominal y flechas predichas por el análisis numérico de elementos finitos para una placa del mismo espesor.

Figure 11. Deflection at the center of the plate obtained experimentally on the plate $P 3$, of nominal thickness of 8.38 $\mathrm{mm}$ and deflection predicted by numerical analysis of finite elements for a plate thickness.

These results again confirm the validity of the numerical simulation. As can be seen in the Figure 10 and the Figure 11 at the time the maintenance of a constant pressure on the laminated glass causes an increase of the deflection is not insignificant. Thus the tested plates made 2000 Pa pressure in an initial time of $120 \mathrm{~s}$ to go after $11.5 \mathrm{~min}$ an deflection a $2.5 \%$ higher in the case of the plate of $6.38 \mathrm{~mm}$ as in $8.38 \mathrm{~mm}$.

\section{CONCLUSIONS}

From the discussion of the results of this study can be concluded that predictions of the numerical modelling presented here correspond to a large extent with what was observed experimentally. The tests conducted have not been limited to measuring an deflection after you apply an end load but has been taken into account the viscoelastic nature of the polymer film which is in PVB glass laminate testing at different speeds of implementation of loads and to maintain them over time. Of tests has been proven an effective way the influence exerted by mechanical polymer film on the set of laminated glass which will ultimately involve the variation of the tension of glass. Thus, with increased loading speed, the deflection obtained is less for a given time because there is less time for flow of viscoelastic material. On the other hand has shown that as time passes the relative displacement between the glass plates in favor of the viscoelastic layer decreases the stiffness of the laminate, resulting in greater deflections. It follows from the desirability of controlling the viscoelastic properties of the inner polymer sheet 
hace disminuir la rigidez del laminado observándose mayores flechas. De lo anterior se infiere la conveniencia del control de las propiedades viscoelásticas de la lámina polimérica interior dependiendo de si las cargas son de corta duración (impacto) o de larga duración.

\section{AGRADECIMIENTOS}

Los autores agradecen al Ministerio de Ciencia y Tecnología la financiación del trabajo presentado a través del proyecto de investigación "Modelo probabilístico para cálculo de placas de vidrio laminado: propuesta de norma para edificación" (Ref. MEC-05-BIA2005-03143). depending on whether the loads are short (impact) or long duration.

\section{ACKNOWLEDGMENTS}

The authors thank the economical support of this work for the Ministerio de Ciencia y Tecnología trough the research project "Probabilistic Model for calculation of laminated glass plates: proposed standard for construction (Ref. MEC-05-BIA2005-03143).

\section{BIBLIOGRAFÍA / BIBLIOGRAPHY}

(1) Bennison, S. J.; Jagota, A.; Smith, C. A.: "Fracture of glass/poly(vinyl butyral) (Butacite) laminates in biaxial flexure", Journal of the American Ceramic Society, vol. 82, n० 7 (1999), pp. 1761-1770.

(2) Simulia Inc.: "ABAQUS/CAE version 6.7.2. Manual" (2007).

(3) Haldimann, M.; Luible, A.; Overend, M.: "Structural Use of Glass", IABSE-AIPC-IVBH, Zürich, 2008.

(4) CEN. EN 572-1:2004, "Glass in building - Basic soda lime silicate glass products - Part 1: Definitions and general physical and mechanical properties".

(5) Ferry, J. D.: "Viscoelastic Properties of Polymers", Wiley, 1980.

(6) Gere, J. M.: "Resistencia de Materiales", Thomson, 2002.

(7) Park, S. W.; Schapery, R. A.: "Methods of interconversion between linear viscoelastic material functions. Part I - A numerical method based on Prony series", International Journal of Solids and Structures, vol. 36, nº 11 (1999), pp. 1653-1675.

(8) Luhmann, T.; Robson, S.; Kyle, S.; Harley, I.: "Close Range Photogrammetry - Principles, Methods and Aplications", Whittles Publishing, 2006. 